Biogeosciences, 10, 2513-2524, 2013

www.biogeosciences.net/10/2513/2013/

doi:10.5194/bg-10-2513-2013

(C) Author(s) 2013. CC Attribution 3.0 License.

\title{
Impact of human activities on organic carbon transport in the Yellow River
}

\author{
L. J. Zhang ${ }^{1}$, L. Wang ${ }^{1}$, W.-J. Cai ${ }^{2}$, D. M. Liu ${ }^{1}$, and Z. G. Yu ${ }^{3}$ \\ ${ }^{1}$ Key Laboratory of Marine Environment and Ecology, Ministry of Education, College of Environmental Science and \\ Engineering, Ocean University of China, Songling Road 238, Laoshan District, Qingdao 266100, China \\ ${ }^{2}$ School of Marine Science and Policy, University of Delaware, Newark, DE 19716, USA \\ ${ }^{3}$ Institute of Marine Organic Geochemistry, College of Chemistry and Chemical Engineering, Ocean University of China, \\ Songling Road 238, Laoshan District, Qingdao 266100, China
}

Correspondence to: L. J. Zhang (longjunz@ ouc.edu.cn)

Received: 2 October 2012 - Published in Biogeosciences Discuss.: 17 October 2012

Revised: 25 March 2013 - Accepted: 26 March 2013 - Published: 15 April 2013

\begin{abstract}
Using data from four field investigations between 2003 and 2009 along the Yellow River mainstream, we examined the transport features and seasonal variations of organic carbon, with a focus on contrasting the impacts of human activities with those of natural processes. Particulate organic carbon (POC) in the Yellow River originated mainly from the Loess Plateau, and thus the POC content in suspended sediments was much lower than in the world's other large rivers. Owing to both natural and human influences, dissolved organic carbon (DOC) has only a weak correlation with discharge. DOC varied as a result of human activities such as agricultural irrigation and pollution in the whole basin except for the upstream Qinghai-Tibetan Plateau. Our study also suggested that while reservoirs are a POC sink over short periods, a long-term POC storage flux cannot be easily estimated as discharge and sediment regulations have completely changed the relationship between the fluxes of water, sediments, and rainfall. However, this carbon sink can be obtained reliably through high-frequency sampling over long time periods. In addition, the annual water and sediment regulation (WSR) scheme has imposed an extremely severe human disturbance on the transport pattern of river organic carbon. Our study demonstrated for the first time that in a WSR event of less than 20 days, large proportions of the annual DOC (35\%) and POC (56\%) fluxes of the Yellow River were transported to the estuarine and coastal zone, potentially influencing estuarine and coastal geochemistry and ecosystems profoundly.
\end{abstract}

\section{Introduction}

Rivers play an important role in the global carbon cycle by linking land and ocean systems, which are the two largest carbon reservoirs on the earth's surface (Dagg et al., 2004). Biogeochemical properties in rivers also reflect the integrated natural processes and anthropogenic activities within the drainage basins; in particular, the forms, sources, and dynamics of riverine organic materials are very important because they influence water quality, fishery production, and the global carbon budget (Meybeck, 1982; Balakrishna and Probst, 2005). Globally, rivers transport about $380 \mathrm{Tg} \mathrm{Ca}^{-1}$ (organic carbon) to the ocean, of which 50 to $60 \%$ is in the dissolved form (Ludwig et al., 1996). The total amount of organic carbon transported by global rivers accounts for about $17 \%$ of the net carbon accumulation on continents or in oceans (Aufdenkampe et al., 2011). Consequently, it is of great importance to understand the transport mechanisms and characteristics of riverine organic carbon to advance global carbon cycle research.

Recent studies of riverine organic carbon focused mainly on rivers in regions with semihumid or humid climates, such as the Amazon River (Hedges et al., 1986, 1994; MoreiraTurcq et al., 2003a; Townsend-Small et al., 2008; Neu et al., 2011; Cerri et al., 2012), the Mississippi River (Wang et al., 2004; Dubois et al., 2010; Bianchi et al., 2004, 2007, 2011), the Congo River (Coynel et al., 2005; Spencer et al., 2012) and the Yangtze River (Wu et al., 2007; Wang et al., 2012). In contrast, very few efforts have focused on rivers in arid and 
semiarid regions. For example, in the Indus River (Ittekkot et al., 1986; Ittekkot and Arain, 1986) and the Ganges (Ittekkot et al., 1985, 1986) seasonal variations of the organic carbon distribution and the influences of sediment flux on organic carbon transport were studied. The Tana River (East Africa), which is located in a low-latitude region and flows through semiarid plains, was studied in detail concerning its high turbidity and seasonal variations of organic carbon distribution (Bouillon et al., 2007, 2009; Tamooh et al., 2012).

Milliman et al. (2008) found that 34 representative world rivers suffered from $30 \%$ declines in discharge due to damming, irrigation, and interbasin water transfers, and 18 of those (including the Indus and the Yellow River) experienced more than a $50 \%$ decline. Most of these rivers drain arid and semiarid regions in Africa, Asia, and Australia. The Yellow River is situated in a midlatitude region with an arid and semiarid climate, and it is one of the largest rivers in the world in terms of sediment delivery. The material transport of the Yellow River is also intensively affected by human activities. Using data from four field investigations of the Yellow River mainstream, we intend to illustrate the temporal-spatial distribution features of organic carbon, especially variations induced by agricultural irrigation, reservoir construction, and the water and sediment regulation (WSR) scheme. This is also the first study of organic carbon transport during a WSR event. Our work not only provides basic data informing studies of the global carbon budget but also discusses changing organic carbon transport features due to human disturbances, and thus it emphasizes the importance of finding a balance between development and the impact on carbon cycle and ecosystems.

\section{Data collection and analytical methods}

\subsection{Study area}

The Yellow River originates from the Yueguzonglie Basin on the Qinghai-Tibetan Plateau at an elevation of $4500 \mathrm{~m}$. It flows about $5464 \mathrm{~km}$ and drains $75.2 \times 10^{4} \mathrm{~km}^{2}$ before discharging into the Bohai Sea (Fig. 1).

The area upstream of the Huayuankou station (QinghaiTibetan Plateau and Loess Plateau) accounts for about $97 \%$ of the entire Yellow River basin, while that downstream of the Huayuankou station, characterized by a raised riverbed running over the surrounding ground, only occupies $3 \%$ (Wang et al., 2006, 2007). Moreover, the Yellow River is one of the most turbid rivers in the world. It has multiple sources of water and sediment. Water comes mainly from the Qinghai-Tibetan Plateau while sediment principally originates from the Loess Plateau (Fig. 1) (Zhang et al., 1990). In addition, most of the Yellow River basin is located in arid and semiarid regions, where annual evaporation $(1712 \mathrm{~mm})$ greatly exceeds precipitation $(440 \mathrm{~mm})$. This is especially true in the Loess Plateau region. Furthermore, most rain-

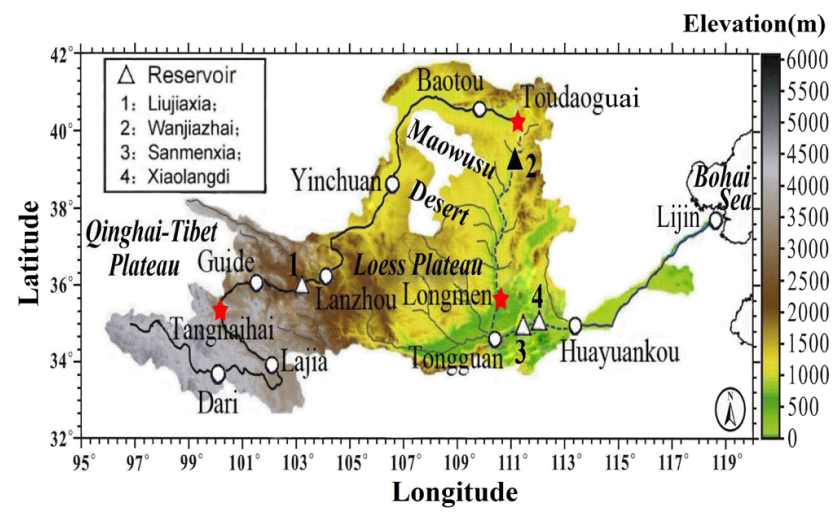

Fig. 1. Map of the Yellow River basin, which consists of two main geographical units, the Qinghai-Tibetan Plateau and the Loess Plateau (quoted from Wang et al., 2010). Sampling stations are indicated by open symbols. Wanjiazhai reservoir (marked as 2) is one of the most important sites for the water and sediment regulation scheme. Red stars denote additional hydrological stations, whose discharge data are also used (see text for explanation).

fall occurs in the wet season (June-September) (Yang et al., 2004). It is also important to note that the soil organic matter content is much higher in the Qinghai-Tibetan Plateau $(\sim 6.6 \%)$ (Zeng et al., 2004) than that in the Loess Plateau $(0.6 \%)$ (Wen, 1989).

Owing to climate change, reservoir construction, and irrigation, annual water and sediment fluxes of the Yellow River have declined greatly in recent years (Wang et al., 2006, 2007; Milliman et al., 2008). Furthermore, to flush sediment trapped in the watercourse and reservoirs away and prepare for the coming floods, the Yellow River Conservancy Commission carried out WSR trials in the middle reach during the early wet season (late June and early July) between 2002 and 2005 and has put this procedure into formal operation since 2005. The WSR scheme consists of two periods: the first is the water release period (period I), characterized by a large amount of upper clear water discharge from the Xiaolangdi reservoir to flush the waterway downstream; and the second phase is the sediment release period (period II), featured by flushing out deposited sediment from the Xiaolangdi reservoir using water discharge from the upstream reservoirs.

In our research, the Yellow River mainstream is divided into three reaches according to its geographic features. The upper Qinghai-Tibetan Plateau reach is located between the river origin and the Lanzhou station, while the middle Loess Plateau reach is situated between the Lanzhou station and the Huayuankou station. The reach below the Huayuankou station, where the riverbed is generally above the surrounding areas, is considered the lower reach (Fig. 1).

\subsection{Data}

Four field investigations along the Yellow River mainstream were carried out in October 2003, November 2006, 
July 2007, and July 2009. In addition, field observations were also conducted once a week at the Huayuankou station from November 2005 to November 2006 and daily at the Lijin station during the $2008 \mathrm{WSR}$ period. Samples for studying TSS (total suspended solids) classification were taken during the 2006 period.

In this paper, annual/monthly discharge, water consumption, and return flow data are quoted from the Yellow River Water Resources Bulletin (2005-2010) and the Yellow River Sediment Bulletin (2005-2006). For sampling sites where no hydrological data are available, we applied average values from the neighboring stations instead (these additional hydrological stations are marked with red stars in Fig. 1). The Tangnaihai and the Toudaoguai hydrological stations are about $200 \mathrm{~km}$ from the Guide and the Baotou sampling sites, respectively, while the Longmen hydrological station is about $100 \mathrm{~km}$ upstream from the Tongguan station.

\subsection{Sampling and analysis}

Water samples were collected at least $50 \mathrm{~cm}$ beneath the water surface with a Niskin bottle. Methods for determining the parameters are described below.

Total suspended solids (TSS): samples were processed first by filtering through $0.45 \mu \mathrm{m}$ preweighed cellulose acetate membrane filters. Then, the filters were dried at $45-50{ }^{\circ} \mathrm{C}$ and weighed with an electronic balance (AL 104, Mettler Toledo, Switzerland). The precision of the measurement was $0.0001 \mathrm{~g}$.

Particulate organic carbon (POC), dissolved organic carbon (DOC): preweighed and precombusted GF/F glass-fiber filters (Whatman, Maidstone, UK) were used to separate POC and DOC in the field. Filtrates were collected in precombusted bottles and poisoned with saturated $\mathrm{HgCl}_{2}$ for DOC analysis. Upon returning to the laboratory, filters were added with few drops of $2 \mathrm{~mol} \mathrm{~L}^{-1} \mathrm{HCL}$ and put in a closed container with HCL fumes for $24 \mathrm{~h}$ to remove inorganic carbon, and then they were dried at $45^{\circ} \mathrm{C}$ (Harris et al., 2001; Tamooh et al., 2012). After that, the high temperature oxidation method was used to determine POC with an elemental analyzer (Vario ELIII CHONS, Germany). In addition, DOC was determined using a high-temperature catalytic oxidation technique with the Shimadzu TOC analyzer (He et al., 2010; Zhang et al., 2012).

Chlorophyll $a(\mathrm{Chl} a)$ : Chl $a$ was determined using a fluorescence spectrophotometer (F-4500, Hitachi Co. Japan) after the membrane samples had been extracted with $90 \%$ acetone. The standard curve was constructed with the Sigma C5753 (Sigma Co. Japan).

TSS classification: The water elutriation system, based on Stokes' principle (Walling and Woodward, 1993; Zhang et al., 2009) and Mastersize-2000 (Malvern Co. UK), was used to classify the particles into five categories: $<8 \mu \mathrm{m}, 8-16 \mu \mathrm{m}$, $16-32 \mu \mathrm{m}, 32-63 \mu \mathrm{m}$ and $>63 \mu \mathrm{m}$. The measuring range of
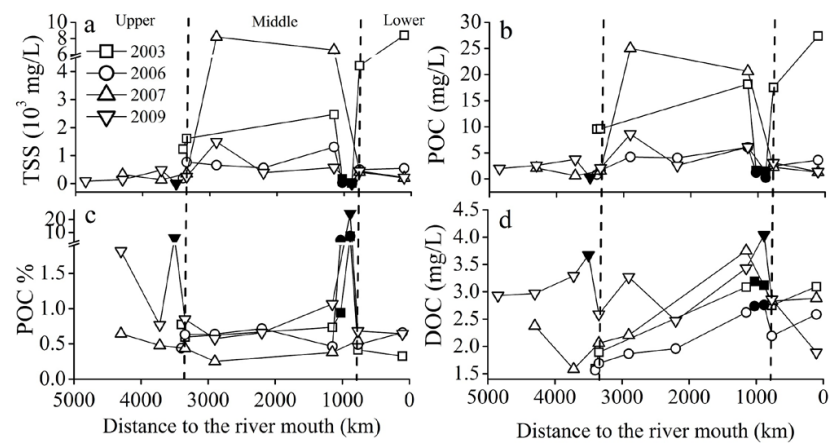

Fig. 2. Spatial and temporal variations of TSS (a), POC (b), POC \% (c) and DOC (d) along the mainstream of the Yellow River (solid symbols represent data from the reservoirs). The upper reach is located above the Lanzhou station while the middle reach is situated between the Lanzhou station and the Huayuankou station. The reach below the Huayuankou station is considered the lower reach.

the instrument is $0.02-2000 \mu \mathrm{m}$ and the precision is better than $3 \%$ on replicate analyses.

\section{Results}

\subsection{Yellow River mainstream}

TSS along the Yellow River mainstream (reservoirs excluded) ranged from 90 to $8400 \mathrm{mg} \mathrm{L}^{-1}$ during our four investigations and consistently showed that TSS was very low in the upper reach, peaked in the middle reach and then decreased in the lower reach (Fig. 2a). Correspondingly, POC showed a similar trend as TSS and ranged between 0.65 and $27.4 \mathrm{mg} \mathrm{C} \mathrm{L}^{-1}$ (Fig. 2b). In addition, POC \% $(\mathrm{POC} / \mathrm{TSS} \times 100 \%)$ of the Yellow River ranged between $0.25 \%$ and $2.2 \%$ (averaged at $0.7 \%$ ), with high and low values appearing in the upper and middle reaches, respectively (Fig. 2c). The DOC concentration distribution was different from that of POC. It increased along the mainstream from the upper reach to the middle reach before decreasing in the lower reach, varying from 1.6 to $3.8 \mathrm{mg} \mathrm{C} \mathrm{L}^{-1}$ (Fig. 2d). Specifically, two phenomena are worth noting: DOC in the upper reach during the 2009 investigation was much higher, and DOC at the Tongguan station was the highest in all four investigations (Fig. 2d). Chl $a$ concentrations changed dramatically along the watercourse $\left(0.5\right.$ and $\left.122 \mu \mathrm{g} \mathrm{L}^{-1}\right)$, with the highest value at the Tongguan station (distribution not presented). POC/Chl $a$ ratio of the Yellow River mainstream averaged at 3988, with the higher values in the middle reach.

The Liujiaxia reservoir (storage capacity, $5.7 \mathrm{~km}^{3}$ ) in the upper reach and the Sanmenxia reservoir $\left(9.7 \mathrm{~km}^{3}\right)$ and Xiaolangdi reservoir $\left(12.7 \mathrm{~km}^{3}\right)$ in the middle reach were selected to analyze the impacts of reservoirs on organic carbon transport. Compared with the mainstream, TSS (4-175 $\left.\mathrm{mg} \mathrm{L}^{-1}\right)$ and POC $\left(0.3-1.7 \mathrm{mg} \mathrm{CL}^{-1}\right)$ were lower, 
whereas DOC (2.7-4 $\left.\mathrm{mg} \mathrm{C} \mathrm{L}^{-1}\right)$ and POC \% (0.1-25\%) were higher in the reservoirs. In addition, Chl $a$ concentrations were generally lower in the reservoirs than the mainstream, ranging between 0.66 and $5.9 \mu \mathrm{g} \mathrm{L}^{-1}$. POC/Chl $a$ ratio in the reservoirs averaged at 964, much lower compared with that of the mainstream.

\subsection{Variations of organic carbon concentrations during a 1 yr observation}

As the lower bound of the middle reach, Huayuankou hydrological station is the ideal place to observe the material transport patterns from the Loess Plateau (Fig. 1). In addition, the Huayuankou station is just $120 \mathrm{~km}$ downstream of the Xiaolangdi reservoir, which is the main reservoir for carrying out the WSR scheme. Thus, it is also an ideal location to monitor material transport patterns from reservoirs during the WSR period.

During the winter period, temperature averaged at about $2{ }^{\circ} \mathrm{C}$ at the Huayuankou station, and the Yellow River mainstream in the upper and middle reaches was almost frozen. Consequently, discharges and concentrations of TSS and POC all stayed at very low levels in winter (Fig. 3). Concentrations of DOC also were low. In late winter (February), temperature increased and the ice melted. As a result, water discharge and concentrations of TSS, POC, and DOC all increased. DOC even achieved its second highest value. During the spring period, discharge and TSS stayed at a high level, whereas POC also increased but fluctuated widely. On the contrary, DOC showed a downward trend. The WSR scheme was carried out between 15 June and 3 July. During this period, discharge, TSS, and POC increased sharply while DOC increased slightly. After the WSR event and during the autumn period, DOC stayed at a relatively high level while other parameters showed decreasing trends, with exceptions caused by precipitation/floods and reservoir water adjustments (i.e., releasing only water, no sediment discharge). Overall, POC fluctuated most among all parameters during the entire observation, especially during the summer season.

\subsection{Variations of organic carbon concentration during the WSR period}

In the previous section, we demonstrated that the concentration of POC and DOC can change greatly during the WSR period in the middle reach. To determine the impacts of the WSR scheme on material transport patterns in the lower reach, the entire WSR period (23 June-10 July) of 2008 was observed at a high resolution (daily) at the Lijin station (Fig. 4). This was the first time that organic carbon transport was studied during an entire WSR event.

One week before the 2008 WSR period, discharge, TSS, POC, DOC, and POC \% averaged at $320 \mathrm{~m}^{3} \mathrm{~s}^{-1}$, $380 \mathrm{mg} \mathrm{L}^{-1}, 4.0 \mathrm{mg} \mathrm{CL}^{-1}, 2.7 \mathrm{mg} \mathrm{CL}^{-1}$ and $1.1 \%$, respectively (Fig. 4). When WSR started, discharge increased

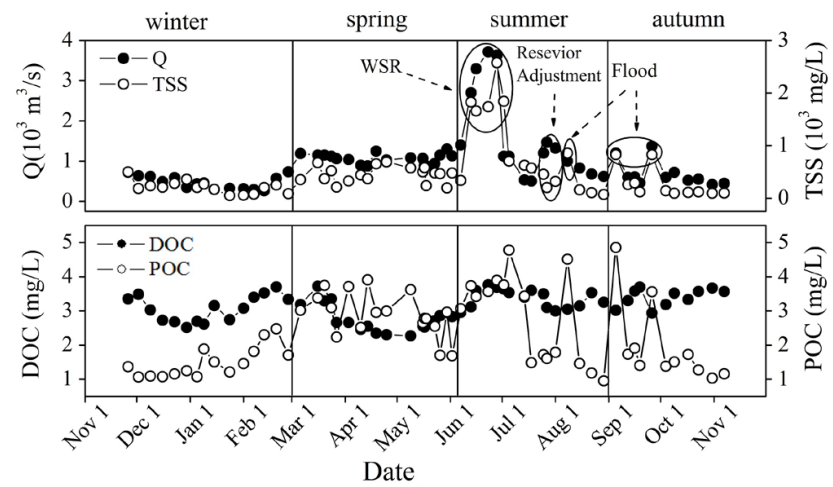

Fig. 3. Distributions of discharge $(Q)$, TSS, POC, and DOC at the Huayuankou hydrological station between November 2005 and November 2006. WSR denotes the water and sediment regulation period and reservoir adjustment indicates that reservoirs start to release water, but not sediment.

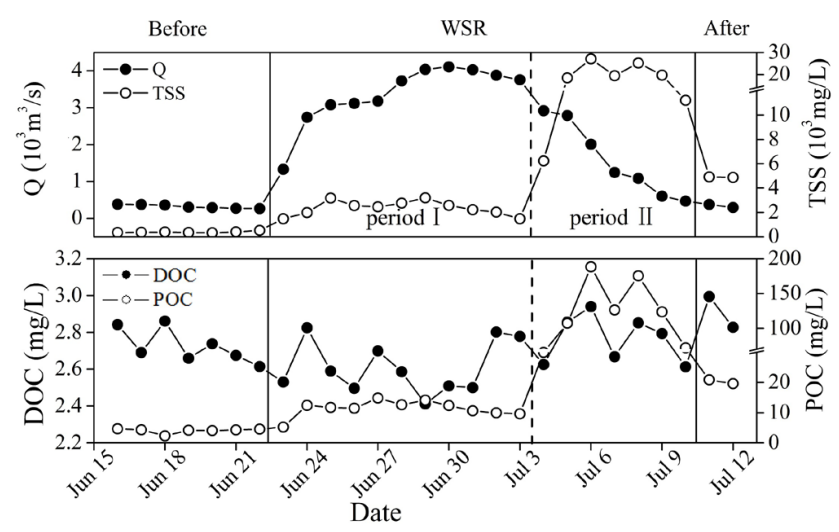

Fig. 4. Distributions of discharge ( $Q$ ), TSS, POC, and DOC before, during, and after the 2008 water and sediment regulation (WSR) period at the Lijin station. Period I stands for the water release period and period II denotes the sediment release period.

greatly from 23 June and achieved the highest value $\left(4110 \mathrm{~m}^{3} \mathrm{~s}^{-1}\right)$ on June 30 due to the large amounts of water released from the Xiaolangdi reservoir (period I). During this period, TSS and POC, respectively, were about 6 and 3 times higher than the values before the event, while DOC fluctuated greatly. In addition, POC $\%$ decreased to about $0.5 \%$. After that, large quantities of small grain size sediments were flushed out from the Xiaolangdi reservoir on 30 June and reached the Lijin station on 4 July (period II). As a result, TSS and POC increased greatly and reached peak values on 6 July (2710 $\mathrm{m} \mathrm{L}^{-1}$ and $188 \mathrm{mg} \mathrm{C} \mathrm{L}^{-1}$ respectively) while DOC also increased to its maximum $\left(2.9 \mathrm{mg} \mathrm{CL}^{-1}\right)$ on the same day. Overall, although TSS and POC each had high variability during the WSR period, they correlated very well with each other $\left(R^{2}=0.99\right)$. In addition, DOC also correlated with POC even though DOC had large variability $\left(R^{2}=0.4\right)$. 

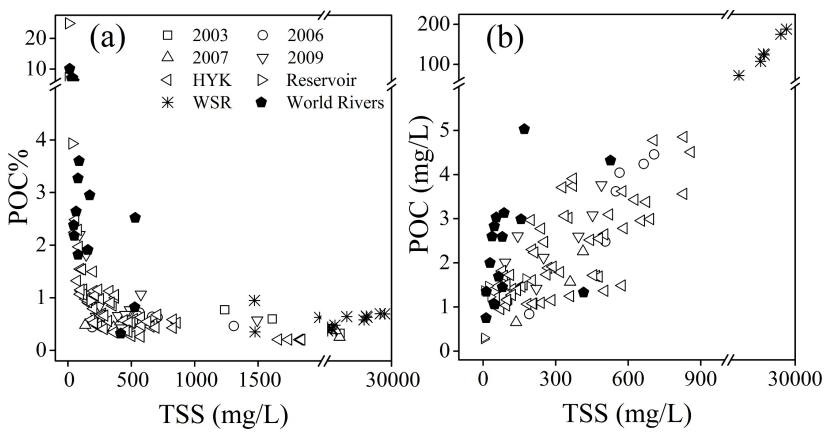

Fig. 5. Relationship between POC \% and TSS (a), and POC and TSS (b) of the Yellow River and world rivers (Ludwig et al., 1996; 2003, 2006, 2007, 2009 indicate the field investigation time along the Yellow River mainstream, respectively; HYK denotes a 1 yr observation at the Huayuankou station between November 2005 and November 2006; WSR indicates the entire water and sediment regulation period in 2008 at the Lijin station).

\section{Discussion}

\subsection{POC transport features of the Yellow River}

POC \% decreased with increasing TSS exponentially in the Yellow River, which is similar to that observed in other rivers (Ludwig and Probst, 1996; Ittekkott, 1988), but the POC content of the Yellow River was lower than the global average (Fig. 5a). POC content was only $0.7 \%$ along the Yellow River mainstream downstream of the Loess Plateau (excluding data from reservoirs), much lower than the average levels of world rivers (Meybeck, 1982; Ludwig et al., 1996). Two reasons have been proposed to explain the low POC content in the Yellow River sediments. First, the Yellow River flows through the biggest and deepest Loess Plateau in the world, which accounts for about $40 \%$ of the whole basin area and contributes $90 \%$ of the sediment in the river (Zhang et al., 1990). The mineral composition of the loess is mainly evaporates, silicates, clays, and carbonates (Zhang et al., 1995), with the average content of organic matter being only $0.6 \%$ (Wen, 1989). As a result, riverine POC would be diluted by mineral materials. Second, TSS of the Yellow River is much higher than that of other rivers (Fig. 5b). As large sediment loads restrict in situ production because of the reduced availability of light in river waters, the autochthonous contribution provided by riverine phytoplankton is very limited. The POC/Chl $a$ ratio of the Yellow River mainstream averaged 4000 (50-22520), much higher than the Tana River (934) (Bouillon et al., 2009; Tamooh et al., 2012), another highly turbid river, and it greatly exceeds values of the Mississippi River (256) (Duan and Bianchi, 2006) and the Yangtze River (48-136) (Yu et al., 2011).

POC $\%$ was very high in the reservoirs, with the highest value even exceeding $20 \%$ (Fig. 5a), probably due to its small grain size particles, which contain a higher amount of
POC after large particles settle. In addition, the POC content in the upper reach was the highest value along the mainstream, which was similar with the situation in the upper Tana River (Tamooh et al., 2012). This was probably caused by high soil organic matter content and low degradation efficiency in the cold, high altitude areas (Zeng et al., 2004; Tamooh et al., 2012). Furthermore, heavy rainfall before our sampling period in 2003 caused intense scouring, resulting in very high TSS and POC concentrations in the middle and the lower reaches (Fig. 2a, b).

As sediments carry POC, and their grain size determines the total effective bearing area of organic matter (Walling and Woodward, 1993), we will discuss the role of grain size in POC transport. In our analysis, we divided TSS into five categories: $<8 \mu \mathrm{m}, 8-16 \mu \mathrm{m}, 16-32 \mu \mathrm{m}, 32-63 \mu \mathrm{m}$ and $>63 \mu \mathrm{m}$, and determined the POC content of each category during our 2006 field study (Table 1). It should be noted that the 2006 investigation was carried out almost in winter, when the impacts of rainfall and human disturbances were insignificant, so the POC content represented mainly the natural features of POC in the middle and lower reaches.

Although the POC content in the same category varied between different locations, more than $75 \%$ of the POC was concentrated in particles with grain size smaller than $16 \mu \mathrm{m}$, while over $85 \%$ of POC was found in particles smaller than $32 \mu \mathrm{m}$. In conclusion, the TSS grain size was the dominant factor controlling POC transport in the middle and lower reaches of the Yellow River.

\subsection{DOC transport features of the Yellow River}

DOC along the Yellow River mainstream was much lower than that in other world rivers (Ludwig et al., 1996), probably due to the low rainfall (Yang et al., 2004), low vegetation coverage (Wang et al., 2001) and low organic matter content in the loess (Wen, 1989). In addition, the very high TSS content may also be an important reason for the very low DOC concentration owing to adsorption of DOC onto particles (Moreira-Turcq et al., 2003b). However, because it was affected by natural and anthropogenic factors, DOC along the mainstream still showed clear spatial and temporal differences.

First, soil organic matter content in the Qinghai-Tibetan Plateau is higher compared with that in other regions of the Yellow River basin (Zeng et al., 2004), and this region is also the water source area of the Yellow River. As a result, the strong leaching effect of high organic matter soils may have caused relatively high DOC concentrations in the upper reach (Finlay et al., 2006). Furthermore, we noticed that DOC in the upper reach was much higher in 2009 than 2007 (Fig. 2). We speculated that this difference may be related to temperature variations in the Qinghai-Tibetan Plateau. July temperature in $2009\left(11.3^{\circ} \mathrm{C}\right)$ was about $2^{\circ} \mathrm{C}$ higher than that in $2007\left(9.5^{\circ} \mathrm{C}\right)$. Higher temperature might have led to faster 
Table 1. The median size $\left(d_{0.5}\right)$ and POC \% for each grain size and the original samples (2006 investigation).

\begin{tabular}{llrrrrrr}
\hline Station & & $\Phi_{<8 \mu \mathrm{m}}$ & $\Phi_{8-16 \mu \mathrm{m}}$ & $\Phi_{16-32 \mu \mathrm{m}}$ & $\Phi_{32-63 \mu \mathrm{m}}$ & $\Phi_{>} 63 \mu \mathrm{m}$ & Original samples \\
\hline \multirow{2}{*}{ Lanzhou } & $d_{0.5}(\mu \mathrm{m})$ & 3.9 & 8.3 & 21.9 & 42.3 & 71.1 & 7.2 \\
& POC $\%$ & $0.51 \%$ & $0.43 \%$ & $0.28 \%$ & $0.14 \%$ & $0.09 \%$ & $0.44 \%$ \\
\multirow{2}{*}{ Tongguan } & $d_{0.5}(\mu \mathrm{m})$ & 3.9 & 10.0 & 26.8 & 51.7 & 89.2 & 17.4 \\
& POC $\%$ & $0.48 \%$ & $0.41 \%$ & $0.23 \%$ & $0.14 \%$ & $0.09 \%$ & $0.46 \%$ \\
\multirow{2}{*}{ Huauankou } & $\mathrm{d}_{0.5}(\mu \mathrm{m})$ & 3.6 & 9.2 & 23.7 & 48.8 & 78.7 & 10.6 \\
& POC $\%$ & $0.59 \%$ & $0.52 \%$ & $0.30 \%$ & $0.13 \%$ & $0.12 \%$ & $0.49 \%$ \\
Lijin & $d_{0.5}(\mu \mathrm{m})$ & 3.6 & 9.2 & 23.7 & 50.7 & 71.5 & 18.6 \\
& POC $\%$ & $0.48 \%$ & $0.40 \%$ & $0.18 \%$ & $0.067 \%$ & $0.04 \%$ & $0.66 \%$ \\
\hline
\end{tabular}

snow melting and thus a stronger leaching effect (Finlay et al., 2006) on the soils with high organic matter content.

Second, there was a clear increase in DOC concentration in the middle reach during all our investigations (Fig. 2d), and this may have been caused by the severe human influences affecting the area, mainly the agricultural pollution. About 100 million people live in the Yellow River basin, and the catchment consists of $1.2 \times 10^{5} \mathrm{~km}^{2}$ of farmland, nearly half of which is irrigated by the Yellow River (Yang et al., 2004). In recent years, water consumption (mainly for irrigation) in the Yellow River basin $\left(29 \mathrm{~km}^{3} \mathrm{a}^{-1}\right)$ has been 1.6 times greater than the water flux at the Lijin hydrologic station $\left(18 \mathrm{~km}^{3} \mathrm{a}^{-1}\right)$, and nearly $70 \%$ of that is consumed in the middle reach (Yellow River Water Resources Bulletin, 2005-2010). Inefficient irrigation methods (mainly flood irrigation) resulted in a large amount of high-DOC water returning back to the Yellow River (Zhang et al., 2008). Taking the Ningxia irrigation district (around the city of Yinchuan in Fig. 1) as an example, about $8 \mathrm{~km}^{3} \mathrm{a}^{-1}$ of water were diverted from the Yellow River for irrigation, mainly during May to September, but more than $50 \%$ returned back to the river (Luo et al., 2010). In addition, impacts of domestic sewage and industrial wastewater cannot be ignored. This is especially true with highly contaminated Yellow River tributaries. In particular, the severely polluted Wei River has a water quality worse than Grade V (Yellow River Water Resources Bulletin), and it discharges into the Yellow River at the lower part of the middle reach. This is why we observed high concentrations of organic carbon at the Tongguan station during all our investigations (Fig. 2d).

Finally, in addition to anthropogenic inputs, a concentration effect is also expected. This is because the Yellow River basin is located mainly in arid and semiarid climate regions, and its evaporation is 3-4 times the precipitation; this ratio is even higher in the Loess Plateau region (Table 2). Therefore, the concentration effect on DOC cannot be ignored and it is expected to contribute to the increase of DOC downstream of the Lanzhou station.

\subsection{Annual organic carbon transport features at the Huayuankou station}

Weekly field observations were conducted at the Huayuankou station from November 2005 to November 2006 and demonstrated the following interesting features.

First, in the winter, with low terrestrial input and settlement of large particles, TSS and POC decreased, but POC \% was the highest among all the seasons. In addition, because of the removal of light limitation, Chl $a$ concentrations were much higher in the winter $\left(5 \mu \mathrm{g} \mathrm{L}^{-1}\right)$ compared with other seasons $\left(2 \mu \mathrm{g} \mathrm{L}^{-1}\right)$. Ratios of POC/Chl $a$ were as low as 386 , and therefore autochthonous contributions were the highest in the winter. In addition, POC and DOC increased in January and February, but TSS and discharge changed little. This situation was probably due to the wastewater input from the two large regional cities: Zhengzhou and Luoyang. This kind of human disturbance can be magnified in the winter season when river discharge is low.

Second, because of the WSR scheme, discharge and TSS clearly increased in June, and they were several times higher than those of other months. As the Huayuankou station is only $120 \mathrm{~km}$ downstream of the Xiaolangdi reservoir, which is the dominant site for and the driving force of the WSR scheme, DOC and POC here are mainly influenced by the water and sediment discharged from the reservoir rather than from the watercourse. More specifically, due to the high DOC in the reservoir, the observed DOC concentration at the Huayuankou station was also high, while POC varied with TSS.

Third, after the WSR scheme, variations of POC and DOC were caused mainly by reservoir adjustment (which releases water, but not sediment) and floods. More specifically, if reservoirs upstream only released water, but not sediment, discharge and DOC increased (due to high DOC content in reservoirs) but TSS and POC changed little (reservoir adjustment in Fig. 3). However, during heavy rainfall periods, TSS and POC increased together with discharge, while DOC declined because of dilution (floods in Fig. 3). Finally, monthly discharge and precipitation did not follow each other because of human interventions (Fig. 6). For example, discharge in 
Table 2. Decadal averages of precipitation and evaporation. $P$ is annual precipitation, $E$ denotes annual pan evaporation, $E / P$ is the ratio of the evaporation to precipitation, which shows the dryness of the climate. Data quoted from Yang et al. (2004).

\begin{tabular}{lccc|ccc}
\hline & \multicolumn{3}{c}{ Qinghai-Tibetan Plateau } & \multicolumn{2}{c}{ Qinghai-Tibetan Plateau and Loess Plateau } \\
\hline Decade & $P\left(\mathrm{~mm} \mathrm{a}^{-1}\right)$ & $E\left(\mathrm{~mm} \mathrm{a}^{-1}\right)$ & $E / P$ & $P\left(\mathrm{~mm} \mathrm{a}^{-1}\right)$ & $E\left(\mathrm{~mm} \mathrm{a}^{-1}\right)$ & $E / P$ \\
\hline $1951 \sim 1960$ & 424.6 & 1521 & 3.58 & 444.0 & 1731 & 3.90 \\
$1961 \sim 1970$ & 459.5 & 1410 & 3.07 & 465.9 & 1756 & 3.77 \\
$1971 \sim 1980$ & 456.0 & 1383 & 3.03 & 436.3 & 1763 & 4.04 \\
$1981 \sim 1990$ & 470.0 & 1301 & 2.77 & 446.6 & 1630 & 3.65 \\
$1991 \sim 2000$ & 434.7 & 1377 & 3.17 & 408.4 & 1682 & 4.12 \\
\hline
\end{tabular}

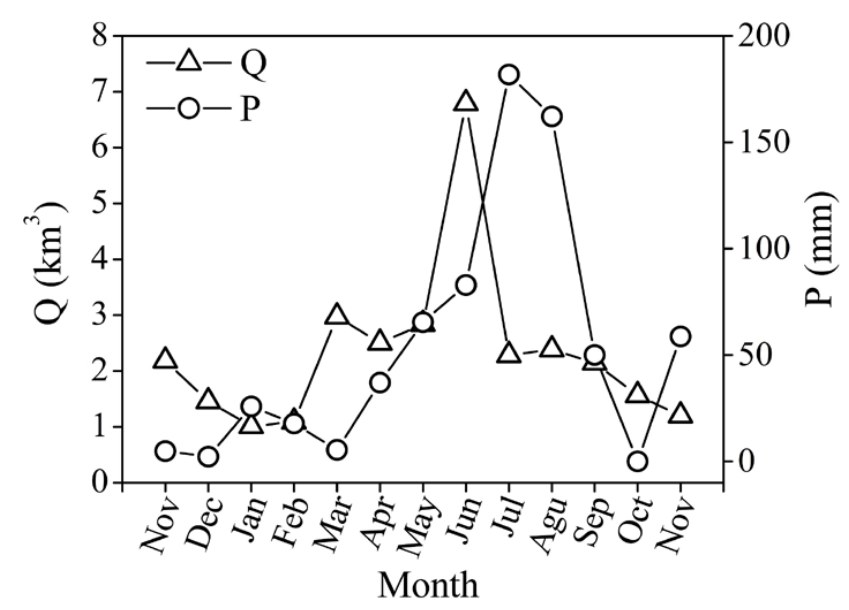

Fig. 6. Monthly precipitation $(P)$ and discharge $(Q)$ during the 1 yr observation (between November 2005 and November 2006) at the Huayuankou station (precipitation data was quoted from http://cdc.cma.gov.cn/home.do and discharge data was quoted from the Yellow River Sediment Bulletin, 2005-2006).

June was the highest owing to the WSR scheme, but it stayed at medium levels during the highest rainfall in July. Reservoir impoundment was responsible for this unnatural phenomenon.

In conclusion, it is clear that human activities dominated the overall organic carbon distributions, and the impacts of natural processes such as rainfalls and floods in the wet season were weakened due to reservoir regulations in the Yellow River mainstream.

\subsection{Impacts of reservoirs on the organic carbon transport in the Yellow River}

More than 3000 reservoirs have been built over the Yellow River and tributaries; the total storage capacity exceeds $57.4 \times 10^{9} \mathrm{~m}^{3}$, which is more than three times the annual net water flux $\left(18 \mathrm{~km}^{3} \mathrm{a}^{-1}\right)$ to the Bohai Sea (Yellow River Sediment Bulletin, 2005-2010). In addition, of the total storage capacity, more than $50 \%$ is scattered in the middle reach (Zhang et al., 2001; Wang et al., 2006). The Yellow River has extremely high turbidity, and therefore its material trans- port suffers more from reservoir construction. This impact can be illustrated by a comparison between the Xiaolangdi reservoir and the Three Gorges Dam of the Changjiang, the largest reservoir in the world. Although the storage capacity of the Xiaolangdi reservoir $\left(12.7 \mathrm{~km}^{3}\right)$ was only $30 \%$ of that of the Three Gorges Dam $\left(39.3 \mathrm{~km}^{3}\right)$, the amount of trapped sediments in the former $\left(240 \mathrm{Tg} \mathrm{a}^{-1}\right)$ was about twice that in the latter (130 $\mathrm{Tg} \mathrm{a}^{-1}$ ) (Dai et al., 2009). Finally, most of suspended sediments would deposit to the bottom of the reservoirs, thus POC in the water decreased dramatically. Meanwhile, due to the removal of light limitation, autochthonous contributions increased (POC/Chl $a$ averaged at 964), so did the DOC concentrations (Parks and Baker, 1997). As a result, $\mathrm{DOC} / \mathrm{POC}$ ratios in the reservoirs were much higher, which were completely different from those of the mainstream.

The Loess Plateau contributes about $90 \%$ of the sediment load to the Yellow River (Zhang et al., 1990). Thus, sedimentation in the reservoirs occurred mainly in the middle reach. If we scaled up the sediment trapping efficiency in the Xiaolangdi reservoir $\left(240 \mathrm{Tg} \mathrm{a}^{-1}\right)$ (Dai et al., 2009), the total sediment trapped in the reservoirs along the middle reach would be $550 \mathrm{Tg} \mathrm{a}^{-1}$, which is about $7 \%$ of the global trapping (Dean and Gorham, 1998). As the POC content of the loess was about $0.6 \%$ (Wen, 1989), the POC trapped in these reservoirs amounted to $3.3 \mathrm{Tg} \mathrm{C} / \mathrm{a}$. This is about 8 times the POC flux transported by the Yellow River to the coastal zone $\left(0.39 \mathrm{Tg} \mathrm{C} \mathrm{a}^{-1}\right.$ ) (Wang et al., 2012). This number also accounts for about $2 \%$ of the organic carbon accumulated in reservoirs worldwide (160-200 $\mathrm{Tg} \mathrm{Ca}^{-1}$ ) (Dean and Gorham, 1998; Cole et al., 2007). In addition, the POC in the Yellow River is mainly composed of refractory natural humus with low degradability (Chen et al., 2003, 2004). Therefore, POC deposited in reservoirs in the middle reach of the Yellow River can be considered as a stable short-term carbon sink. However, because of human activities, in particular the WSR scheme, part of the trapped sediments will be delivered to the lower reach and oceans eventually. Unfortunately, these intermittent and sudden disturbances have changed the natural transport patterns completely in the Yellow River, making the estimate of long-term POC storage rather difficult and uncertain. Our study illustrates an extreme example of human interference on the river water, sediment, and 
carbon transport patterns. In addition, reservoir impoundments decrease the water, nutrients, and sediment fluxes to lower reaches, estuarine, and coastal ocean regions (Teodoru and Wehrli, 2005; Dai et al., 2009). As a result, many aspects of the river system itself are influenced, such as fish migration and reproduction, and the Yellow River delta is retreating due to decreased sediment supply from the upper stream drainage basin.

\subsection{Impacts of the WSR scheme on the organic carbon transport in the Yellow River}

In order to flush the sediment deposited in the watercourse and reservoirs away and prepare for the coming floods in the wet season, the Yellow River Conservancy Commission has carried out the WSR scheme since 2002. However, to our best knowledge, there has been no report on how a WSR event influences the pattern of river carbon transport. We also do not know of such a report for any other rivers.

In the water release period from the Xiaolangdi reservoir (period I), large particles deposited in the watercourse were flushed away due to the sharp increase in discharge. This is reflected in the dramatic increase of TSS and POC (Fig. 7). In addition, POC \% decreased to half of its level before the scheme, indicating that TSS originated mainly from the large grain size sediments in the watercourse. During the later part of period I, while discharge stayed at a nearly constant level around $4000 \mathrm{~m}^{3} \mathrm{~s}^{-1}$ (Fig. 7), concentrations of TSS (POC) went through a sharp decline. In addition, DOC showed a slightly increasing trend but fluctuated widely during this period. Water from the reservoir was discharged intermittently in order to flush the large particles in the watercourse away (Fig. 7), and DOC correlated negatively with POC (Fig. 4), indicating that the intermittent decrease of DOC may be caused by the adsorption of large particles (Moreira-Turcq et al., 2003b).

During the sediment release period (period II), the upstream Sanmengxia and Wanjiazhai reservoirs released large amounts of clear water to flush out the small grain size sediment in the Xiaolangdi reservoir, for the purpose of increasing its storage capacity (Liu and Zhang, 2010). As a result, concentrations of TSS and POC increased tremendously to nearly 10 times those in period I (Fig. 7). Concentrations of DOC in period II were also increasing and correlated very well with POC $\left(R^{2}=0.7\right)$ (Fig. 4), indicating that the transformation from POC to DOC happened during period II (Gao, 2000), especially when POC during this period was higher than $100 \mathrm{mg} \mathrm{C} \mathrm{L}^{-1}\left(\mathrm{TSS}>10000 \mathrm{mg} \mathrm{L}^{-1}\right)$.

Another interesting phenomenon we observed during the WSR period is a changing relationship between TSS and water discharge. In period I, TSS and discharge could be expressed as a clockwise hysteresis while they showed a counter-clockwise hysteresis in period II (Fig. 7). This was similar to the result from the Rhine River where clockwise hysteresis seemed to be related to erosion or early sed-

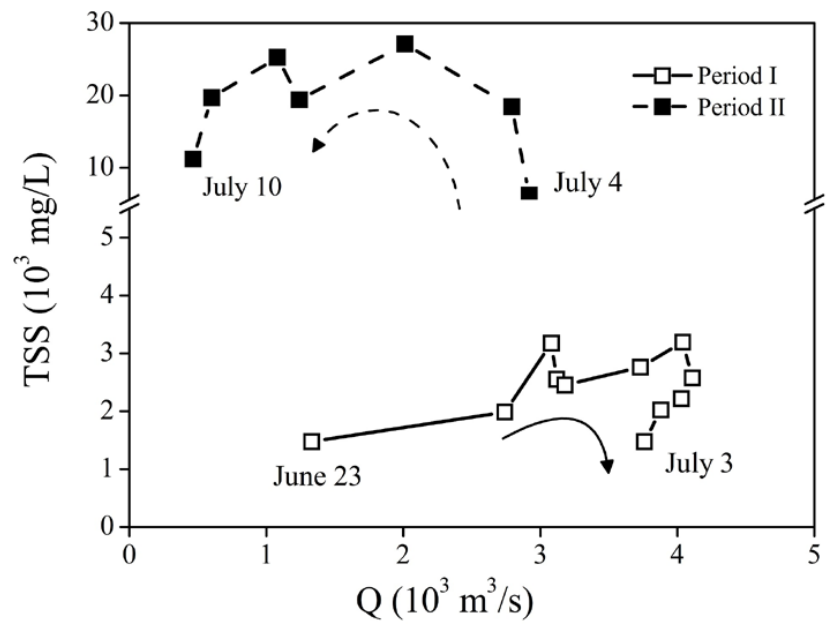

Fig. 7. Relationship between discharge $(Q)$ and TSS in the water release period (period I) and the sediment release period (period II) during the 2008 water and sediment regulation period at the Lijin station.

iment supply just upstream of the measurement location, while counter-clockwise hysteresis occurred during a low discharge period with most of the sediment originating from upstream tributaries (Asselman, 1999). This further strengthened the idea that TSS during period I originated mainly from the large grain size sediment in the watercourse while that in period II came from the upstream reservoir.

According to the average values of DOC, POC, and discharge, we concluded that DOC and POC fluxes during the 2008 WSR period were $0.011 \mathrm{TgC}$ and $0.22 \mathrm{Tg} \mathrm{C}$, respectively, accounting for $35 \%$ of the annual DOC flux $\left(0.032 \mathrm{Tg} \mathrm{Ca}^{-1}\right)$ and $56 \%$ of the annual POC fluxes $\left(0.39 \mathrm{Tg} \mathrm{C} \mathrm{a}^{-1}\right)$ of the Yellow River (Wang et al., 2012). Although the WSR scheme can reduce channel aggradations, improve the flow capacity (Xu et al., 2005) and increase the freshwater supply and eco-environmental qualities in the estuarine zone (Wang, 2005), its negative influences on the ecosystems in the middle and lower reaches, estuarine, and coastal regions are enormous. For example, May to July is the breeding season for aquatic organisms, and the WSR scheme can result in a more than $50 \%$ decrease in fish resources, and fish population diversities also decline greatly (Zhu et al., 2012). Unfortunately, the sediment export flux during the whole $2008 \mathrm{WSR}$ period ( $35 \mathrm{Tg}$ ) only flushed out $15 \%$ of the annual sedimentation of the Xiaolangdi reservoir (Dai et al., 2009). Therefore, the high environmental, ecological, and economic price of the WSR is probably not very rewarding relative to its ability to achieve its goal of flushing sediment deposits and restoring the reservoir capacity.

\subsection{DOC/POC ratio in the Yellow River}

The form of riverine organic carbon during transport has already attracted much attention. Degens et al. (1991) pointed 


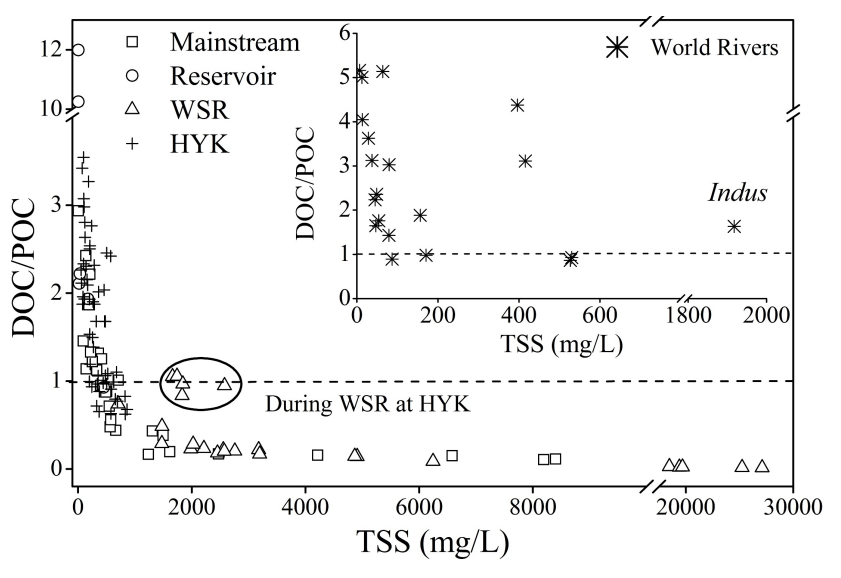

Fig. 8. Relationship between DOC/POC and TSS in the Yellow River and other rivers. WSR denotes the water and sediment regulation scheme of 2008 and HYK indicates the annual observation at the Huayuankou station between November 2005 and November 2006 (inset figure shows this relationship for world rivers, with data from Ludwig et al., 1996 and Dagg et al., 2004).

out that ratios of DOC to POC (DOC/POC) in global rivers ranged between 0.1 and 5 while this value reached 1.5, 3.6, 2.3, and 2.7 for the Amazon River, the Zaire River, the Orinoco River, and the Yangtze River, respectively (Dagg et al., 2004). In other words, riverine organic carbon is primarily transported in the dissolved form (Alvarez-Cobelas et al., 2012).

The DOC/POC ratio fluctuated widely along the Yellow River mainstream because of different geological features and human disturbances. More specifically, the ratio was larger than 1 in the upper reach $(1.4, n=5)$ and in reservoirs $(5.2, n=6)$. On the contrary, the ratios were generally less than 1 in the middle reach and lower reach $(0.74, n=27)$, with the lowest ratio appearing during the WSR period $(0.16$, $n=18$ ).

It is worth noting that the DOC/POC ratio observed at the Huayuankou station for a whole year was almost always larger than 1 (Fig. 3), probably due to the sedimentation of TSS and POC in the upstream Xiaolangdi reservoir. In addition, we shall point out that the DOC/POC ratio observed during the WSR period at the Huayuankou station was much different from what we observed at the Lijin station (Fig. 8). The former only indicated the impact of water and sediment released from its upper stream reservoir, while the latter also represented the water flushing effect on large particles deposited in the watercourse.

If we applied the method used by Abril et al. (2002) to our study, we found that ratios of DOC/POC correlated negatively with TSS (Eq. 1).

$\log (\mathrm{DOC} / \mathrm{POC})=-0.7 \times \log \mathrm{TSS}+1.8\left(R^{2}=0.82, n=111\right)(1)$
Here, when the DOC/POC ratio equals 1, TSS would be $370 \mathrm{mg} \mathrm{L}^{-1}$, suggesting that when TSS exceeds $370 \mathrm{mg} \mathrm{L}^{-1}$, POC is the main form of transported organic carbon; otherwise DOC becomes the dominant form in the Yellow River. From this point of view, POC is the dominant form of organic carbon transported in the Yellow River. Furthermore, it is worth noting that although TSS reached $2000 \mathrm{mg} \mathrm{L}^{-1}$ in the Indus River, the ratio of DOC/POC was still larger than 1 (Fig. 8) (Ludwig et al., 1996). This was probably due to leaching of organics from soils and rocks present in the drainage area (Ittekkot and Arain, 1986). This comparison further contrasts the Yellow River from the world's other large rivers and exemplifies the unique nature of the OC tranport in the Yellow River.

\section{Conclusions}

1. Along the Yellow River, the POC concentration is higher while the POC \% is lower than world average values. Also, POC mainly originates from the loess, and $85 \%$ of the POC is concentrated in particles with grain size smaller than $32 \mu \mathrm{m}$. In addition, different from other large rivers, organic carbon is mainly transported in the particulate form.

2. Due to natural and human influences, DOC correlates weakly with discharge and it varied as a result of human activities such as agricultural irrigation and pollution in the whole basin except for the upstream QinghaiTibetan Plateau.

3. Although sediments trapped in reservoirs can be considered to be stable short-term carbon sinks, regulations on water and sediments have totally changed the relationship between rainfall and fluxes of water and sediments, making its long-term storage capacity uncertain. As a result, the natural riverine transport patterns have been altered and ecosystems in the estuarine and coastal areas have been influenced. Furthermore, the Yellow River delta is retreating due to the decrease in sediment supply from the river.

4. The water and sediment regulation scheme in the Yellow River transports about one-third of the annual DOC flux and one half of the POC flux in about 20 days. This large amount of material that is transported in such a short time seriously influences the riverine system itself and the ecosystems in the estuarine and coastal regions. Therefore, more attention should be paid to study the hydrological, biogeochemical, and ecological impacts of the impoundment of high turbidity rivers.

\section{Supplementary material related to this article is available online at: http://www.biogeosciences.net/10/ 2513/2013/bg-10-2513-2013-supplement.pdf.}


Acknowledgements. This work was supported financially by the National Science Foundation of China (NSFC) (Grant No. 41173107; 40940019) and the Foundation for Innovative Research Groups of National Science Foundation of China (NSFC): Marine Organic Biogeochemistry (Grant No. 41221004). We are thankful to Ming Xue, Zhiyuan Liu, Baosen Wang, Yan Cui and Chunchao Xiao for suggestions. We also would like to express gratitude to Ying $\mathrm{Xu}$ for the contribution to the figures. Insightful comments and suggestions by two anonymous referees and the associate editor significantly improved this manuscript.

Edited by: S. Bouillon

\section{References}

Abril, G., Nogueira, M., Etcheber, H., Cabeçadas, G., Lemaire, E., and Brogueira, M. J.: Behaviour of organic carbon in nine contrasting European estuaries, Estuar. Coast. Shelf S., 54, 241-262, 2002.

Alvarez-Cobelas, M., Angeler, D. G., Sánchez-Carrillo, S., and Almendros, G.: A worldwide view of organic carbon export from catchments, Biogeochemistry, 107, 275-293, 2012.

Asselman, N. E. M.: Suspended sediment dynamics in a large drainage basin: the River Rhine, Hydrol. Process., 13, 14371450, 1999.

Aufdenkampe, A. K., Mayorga, E., Raymond, P. A., Melack, J. M., Doney, S. C., Alin, S. R., Aalto, R. E., and Yoo, K.: Riverine coupling of biogeochemical cycles between land, oceans, and atmosphere, Front. Eco. Environ., 9, 53-60, 2011.

Balakrishna, K. and Probst, J. L.: Organic carbon transport and C/N ratio variations in a large tropical river: Godavari as a case study, India, Biogeochemistry, 73, 457-473, 2005.

Bianchi, T. S., Filley, T., Dria, K., and Hatcher, P. G.: Temporal variability in sources of dissolved organic carbon in the lower Mississippi River, Geochim. Cosmochim. Ac., 68, 959-967, 2004.

Bianchi, T. S., Wysocki, L. A., Stewart, M., Filley, T. R., and McKee, B. A.: Temporal variability in terrestrially-derived sources of particulate organic carbon in the lower Mississippi River and its upper tributaries, Geochim. Cosmochim. Ac., 71, 4425-4437, 2007.

Bianchi, T. S., Wysocki, L. A., Schreiner, K. M., Filley, T. R., Corbett, D. R., and Kolker, A. S.: Sources of terrestrial organic carbon in the Mississippi plume region: evidence for the importance of coastal marsh inputs, Aquat. Geochem., 17, 431-456, 2011.

Bouillon, S., Dehairs, F., Schiettecatte, L. S., and Borges, A. V.: Biogeochemistry of the Tana estuary and delta (northern Kenya), Limnol. Oceanogr., 52, 46-59, 2007.

Bouillon, S., Abril, G., Borges, A. V., Dehairs, F., Govers, G., Hughes, H. J., Merckx, R., Meysman, F. J. R., Nyunja, J., Osburn, C., and Middelburg, J. J.: Distribution, origin and cycling of carbon in the Tana River (Kenya): a dry season basin-scale survey from headwaters to the delta, Biogeosciences, 6, 2475-2493, doi:10.5194/bg-6-2475-2009, 2009.

Cerri, C. C., Bernoux, M., Feigl, B. J., and Cerri, C. E. P.: Carbon Cycling in the Amazon, Recarbonization of the Biosphere, 253273, 2012.

Chen, J. S., He, D. W., and Zhang, Y.: Is COD a suitable parameter to evaluate the water pollution in the Yellow River? Environ. Chem., 22, 611-614, 2003.
Chen, J. S., Zhang, Y., Yu, T., and He, D. W.: A study on dissolution and bio-degradation of organic matter in sediments from the Yellow River, Acta Scientiae Circumstantiae, 24, 1-5, 2004.

Cole, J. J., Prairie, Y. T., Caraco, N. F., McDowell, W. H., Tranvik, L. J., Striegl, R. G., Duarte, C. M., Kortelainen, P., Downing, J. A., and Middelburg, J. J.: Plumbing the global carbon cycle: integrating inland waters into the terrestrial carbon budget, Ecosystems, 10, 172-185, 2007.

Coynel, A., Seyler, P., Etcheber, H., Meybeck, M., and Orange, D.: Spatial and seasonal dynamics of total suspended sediment and organic carbon species in the Congo River, Global Biogeochem. Cy., 19, GB4019, doi:10.1029/2004GB002335, 2005.

Dagg, M., Benner, R., Lohrenz, S., and Lawrence, D.: Transformation of dissolved and particulate materials on continental shelves influenced by large rivers: plume processes, Cont. Shelf Res., 24, 833-858, 2004.

Dai, S. B., Yang, S. L., and Li, M.: The sharp decrease in suspended sediment supply from China's rivers to the sea: anthropogenic and natural causes, Hydrolog. Sci. J., 54, 135-146, 2009.

Dean, W. E. and Gorham, E.: Magnitude and significance of carbon burial in lakes, reservoirs, and peatlands, Geology, 26, 535-538, 1998.

Degens, E. T., Kempe, S., and Richey, J. E.: SCOPE 42: Biogeochemistry of major world rivers, UK, Wiley, 1991.

Duan, S. and Bianchi, T. S.: Seasonal changes in the abundance and composition of plant pigments in particulate organic carbon in the lower Mississippi and Pearl Rivers, Estuar. Coast., 29, 427442, 2006.

Dubois, K. D., Lee, D., and Veizer, J.: Isotopic constraints on alkalinity, dissolved organic carbon, and atmospheric carbon dioxide fluxes in the Mississippi River, J. Geophys. Res., 115, G02018, doi:10.1029/2009JG001102, 2010.

Finlay, J., Neff, J., Zimov, S., Davydova, A., and Davydov, S.: Snowmelt dominance of dissolved organic carbon in high-latitude watersheds: Implications for characterization and flux of river DOC, Geophys. Res. Lett., 33, 10401, doi:10.1029/2006GL025754, 2006.

Gao, Q. Z.: The riverine organic carbon output in subtropical mountainous drainage: the Beijiang River example, Journal of Geosciences of China, 4, 30-37, 2000.

Harris, D., Horwáth, W. R., and van Kessel, C.: Acid fumigation of soils to remove carbonates prior to total organic carbon or carbon-13 isotopic analysis, Soil Sci. Soc. Am. J., 65, $1853-$ 1856, 2001.

He, B., Dai, M., Zhai, W., Wang, L., Wang, K., Chen, J., Lin, J., Han, A., and Xu, Y.: Distribution, degradation and dynamics of dissolved organic carbon and its major compound classes in the Pearl River estuary, China, Mar. Chem., 119, 52-64, 2010.

Hedges, J. I., Clark, W. A., Quay, P. D., Richey, J. E., Devol, A. H., and Santos, U. M.: Compositions and fluxes of particulate organic material in the Amazon River, Limnol. Oceanogr., 31, 717-738, 1986.

Hedges, J. I., Cowie, G. L., Richey, J. E., Quay, P. D., Benner, R., Strom, M., and Forsberg, B. R.: Origins and processing of organic matter in the Amazon River as indicated by carbohydrates and amino acids, Limnol. Oceanogr., 39, 743-761, 1994.

Ittekkot, V.: Global trends in the nature of organic matter in river suspensions, Nature, 332, 436-438, 1988. 
Ittekkot, V. and Arain, R.: Nature of particulate organic matter in the river Indus, Pakistan, Geochim. Cosmochim. Ac., 50, 16431653, 1986.

Ittekkot, V., Safiullah, S., Mycke, B., and Seifert, R.: Seasonal variability and geochemical significance of organic matter in the River Ganges, Bangladesh, Nature, 317, 800-802, 1985.

Ittekkot, V., Safiullah, S., and Arain, R.: Nature of organic matter in rivers with deep sea connections: The Ganges-Brahmaputra and Indus, Sci. Total Environ., 58, 93-107, 1986.

Liu, D. M. and Zhang, L. J.: Temporal and spatial distributions of organic carbon in the Huanghe (Yellow River), Periodical of Ocean University of China, 40, 105-110, 2010.

Ludwig, W., Probst, J. L., and Kempe, S.: Predicting the oceanic input of organic carbon by continental erosion, Global Biogeochem. Cy., 10, 23-41, 1996.

Luo, Y. L., Wang Y. F., Zhang H. M., and Huang F. G.: Impacts of Ningxia-Inner Mongolia irrigation area diversion on the runoff of the Yellow River mainstream, Yellow River, 32, 81-83, 2010.

Meybeck, M.: Carbon, nitrogen, and phosphorus transport by world rivers, Am. J. Sci., 282, 401-450, 1982.

Milliman, J. D., Farnsworth, K. L., Jones, P. D., Xu, K. H., and Smith, L. C.: Climatic and anthropogenic factors affecting river discharge to the global ocean, 1951-2000, Global Planet. Change, 62, 187-194, 2008.

Moreira-Turcq, P., Seyler, P., Guyot, J. L., and Etcheber, H.: Exportation of organic carbon from the Amazon River and its main tributaries, Hydrol. Process., 17, 1329-1344, 2003a.

Moreira-Turcq, P., Seyler, P., Guyot, J. L., and Etcheber, H.: Characteristics of organic matter in the mixing zone of the Rio Negro and Rio Solimoes of the Amazon River, Hydrol. Process., 17, 1393-1404, 2003b.

Neu, V., Neill, C., and Krusche, A. V.: Gaseous and fluvial carbon export from an Amazon forest watershed, Biogeochemistry, 105, 133-147, 2011.

Parks, S. J. and Baker, L. A.: Sources and transport of organic carbon in an Arizona river-reservoir system, Water Res., 31, 17511759, 1997.

Spencer, R. G. M., Hernes, P. J., Aufdenkampe, A. K., Baker, A., Gulliver, P., Stubbins, A., Aiken, G. R., Dyda, R. Y., Butler, K. D., and Mwamba, V. L.: An initial investigation into the organic matter biogeochemistry of the Congo River, Geochim. Cosmochim. Ac., 84, 614-627, 2012.

Tamooh, F., Van den Meersche, K., Meysman, F., Marwick, T. R., Borges, A. V., Merckx, R., Dehairs, F., Schmidt, S., Nyunja, J., and Bouillon, S.: Distribution and origin of suspended matter and organic carbon pools in the Tana River Basin, Kenya, Biogeosciences, 9, 2905-2920, doi:10.5194/bg-9-2905-2012, 2012.

Teodoru, C. and Wehrli, B.: Retention of sediments and nutrients in the Iron Gate I Reservoir on the Danube River, Biogeochemistry, 76, 539-565, 2005.

Townsend-Small, A., McClain, M. E., Hall, B., Noguera, J. L., Llerena, C. A., and Brandes, J. A.: Suspended sediments and organic matter in mountain headwaters of the Amazon River: Results from a 1-year time series study in the central Peruvian Andes, Geochim. Cosmochim. Ac., 72, 732-740, 2008.

Walling, D. E. and Woodward, J. C.: Use of a field-based water elutriation system for monitoring the in situ particle size characteristics of fluvial suspended sediment, Water Res., 27, 1413-1421, 1993.
Wang, G., Qian, J., Cheng, G., and Lai, Y.: Eco-environmental degradation and causal analysis in the source region of the Yellow River, Environ. Geol., 40, 884-890, 2001.

Wang, H. J., Yang, Z. S., Saito, Y., Liu, J. P., and Sun, X. X.: Interannual and seasonal variation of the Huanghe (Yellow River) water discharge over the past 50 years: Connections to impacts from ENSO events and dams, Global Planet. Change, 50, 212225, 2006.

Wang, H. J., Yang, Z. S., Saito, Y., Liu, J. P., Sun, X. X., and Wang, Y.: Stepwise decreases of the Huanghe (Yellow River) sediment load (1950-2005): Impacts of climate change and human activities, Global Planet. Change, 57, 331-354, 2007.

Wang, H., Bi, N., Saito, Y., Wang, Y., Sun, X., Zhang, J. and Yang, Z.: Recent changes in sediment delivery by the Huanghe (Yellow River) to the sea: Causes and environmental implications in its estuary, J. Hydrol., 391, 302-313, 2010.

Wang, K. R.: Impact and evaluation of water and sediment regulation in the Yellow River on the estuary and its delta, J. Sediment Res., 6, 29-33, 2005.

Wang, X. C., Chen, R. F., and Gardner, G. B.: Sources and transport of dissolved and particulate organic carbon in the Mississippi River estuary and adjacent coastal waters of the northern Gulf of Mexico, Mar. Chem., 89, 241-256, 2004.

Wang, X., Ma, H., Li, R., Song, Z., and Wu, J.: Seasonal fluxes and source variation of organic carbon transported by two major Chinese Rivers: The Yellow River and Changjiang (Yangtze) River, Global Biogeochem. Cy., 26, GB2025, doi:10.1029/2011GB004130, 2012.

Wen Q. Z.: Chinese loess geochemistry, Science Press, Beijing, 1989.

Wu, Y., Zhang, J., Liu, S. M., Zhang, Z. F., Yao, Q. Z., Hong, G. H., and Cooper, L.: Sources and distribution of carbon within the Yangtze River system, Estuar. Coast. Shelf S., 71, 13-25, 2007.

Xu, G. B., Zhang, J. L., and Lian, J. J.: Effect of water-sediment regulation of the Yellow River on the lower reach, Advance in Water Science, 16, 518-523, 2005.

Yang, D., Li, C., Hu, H., Lei, Z., Yang, S., Kusuda, T., Koike, T., and Musiake, K.: Analysis of water resources variability in the Yellow River of China during the last half century using historical data, Water Resour. Res., 40, 1-12, 2004.

Yellow River Water Resources Bulletin: The Yellow River Conservancy Commission, 2005-2006.

Yellow River Sediment Bulletin: The Yellow River Conservancy Commission, 2005-2010.

Yu, H., Wu, Y., Zhang, J., Deng, B., and Zhu, Z.: Impact of extreme drought and the Three Gorges Dam on transport of particulate terrestrial organic carbon in the Changjiang (Yangtze) River, J. Geophys. Res., 116, F4029, doi:10.1029/2011JF002012, 2011.

Zeng, Y. N., Feng Z. D., Cao G. C., and Xue L.: The soil organic carbon storage and its spatial distribution of alpine grassland in the source region of the Yellow River, Acta Geographica Sinica, 59, 497-504, 2004.

Zhang, J., Wen Huang, W., and Chong Shi, M. Huanghe (Yellow River) and its estuary: sediment origin, transport and deposition, J. Hydrol., 120, 203-223, 1990.

Zhang, J., Huang, W. W., Letolle, R., and Jusserand, C.: Major element chemistry of the Huanghe (Yellow River), Chinaweathering processes and chemical fluxes, J. Hydrol., 168, 173203, 1995. 
Zhang, X., Wang, L., and Si, F.: Prediction of water consumption in the Huanghe river basin, Water Resources and Hydropower Technology, 6, 8-13, 2001.

Zhang, A. P., Yang, S. Q., Zhang, Q. Z., Yang, S. J., and Yang, Z. L.: Influencing factors and countermeasures of irrigation return flow pollution in Ningxia Yellow River water irrigation district, Chinese Journal of Eco-Agriculture, 16, 1037-1042, 2008.

Zhang, L. J., Zhang, J., and Gong, M. N.: Size distributions of hydrocarbons in suspended particles from the Yellow River, Appl. Geochem., 24, 1168-1174, 2009.
Zhang, L. J., Xue, M., and Liu, Q. Z.: Distribution and seasonal variation in the partial pressure of $\mathrm{CO}_{2}$ during autumn and winter in Jiaozhou Bay, a region of high urbanization, Mar. Pollut. Bull., 64, 56-65, 2012.

Zhu, G. Q., Zhao, R. L., Hu, Z. P., and Hou, X. L.: Impacts of water and sediment Diversion in Xiaolangdi Reservoir on fish and ecologically sensitive areas in the middle Yellow River, Journal of Hydroecology, 33, 7-12, 2012. 